\title{
Impact of turbot fishery on cetaceans in the Romanian Black Sea area
}

\author{
Gheorghe Radu, Eugen Anton \\ National Institute for Marine Research and Development "Grigore Antipa”, 3000 Mamaia Blvd., RO-900581 Constanța, \\ Romania. E-mail: gpr@alpha.rmri.ro
}

\begin{abstract}
Summary: The abundance of the three species of endemic Black Sea marine mammals represented by Delphinus delphis ponticus (Barabasch-Nikiforov 1935), Tursiops truncatus ponticus (Barabasch-Nikiforov 1940) and Phocoena phocoena relicta (Abel 1905) has shown a dramatic decline due to direct killing practiced in earlier times, incidental catches in fishing gears, depletion of the fish populations entering the cetacean food web, and habitat degradation. These threats are more severe in the Black Sea owing to its semi-enclosed nature, high human density, and human activities being carried out especially in coastal zones. Each year, incidental cetacean catches are registered on the Romanian littoral and, consequently, mortalities occur among individuals which strand on the beaches. These mortalities affect in particular the species Phocoena phocoena, considered the most vulnerable one to gillnet fishing. The greatest hazard for Black Sea marine mammals is turbot gillnets, taking into account their number and distribution area. This paper presents data on the description of the current fishing system used in the commercial fisheries of the Romanian Black Sea area, the geographical distribution of the incidental catches, fishing effort, IUU fishing and ghost fishing, CPUE values of cetacean by-catches, indirect impacts of fisheries and recommendations.
\end{abstract}

Keywords: Black Sea; Delphinus delphis ponticus; Tursiops truncatus ponticus; Phocoena phocoena relicta; gillnets; incidental catches; fishing effort; IUU fishing; CPUE values.

Impacto de la pesca de rodaballo sobre los cetáceos del Mar Negro en la costa de Rumanía

Resumen: La abundancia de las tres especies endémicas de mamíferos marinos del Mar Negro, representada por Delphinus delphis ponticus (Barabasch-Nikiforov 1935), Tursiops truncatus ponticus (Barabasch-Nikiforov 1940) y Phocoena phocoena relicta (Abel 1905) ha sufrido una fuerte disminución debido a la matanza directa practicada en épocas anteriores, las capturas accidentales en artes de pesca,, el agotamiento de las poblaciones de peces que forman parte de la cadena trófica de los cetáceos, y la degradación del hábitat. Estas amenazas son más graves en esta zona, debido al carácter semicerrado del Mar Negro, a la alta densidad humana, y a las actividades humanas que se desarrollan especialmente en las zonas costeras. Cada año, se registran capturas accidentals de cetáceos en el litoral rumano y, en consecuencia, se produce la mortalidad entre los individuos que llegan a las playas, sobre todo pertenecientes a la especie Phocoena phocoena, considerados los más vulnerables a la pesca con redes de enmalle. El mayor riesgo para los mamíferos marinos del Mar Negro está representada por las redes de enmalle de rodaballo, teniendo en cuenta su número y distribución del área. El documento presenta datos sobre la descripción del sistema de pesca actual utilizado en las pesquerías comerciales de la zona del Mar Negro rumano, la distribución geográfica de las capturas accidentales, esfuerzo pesquero, la pesca no declarada y no reglamentada IUU y la pesca fantasma, los valores de CPUE de capturas accidentales de cetáceos, impactos indirectos de las pesquerías, así como recomendaciones.

Palabras clave: mar Negro; Delphinus delphis ponticus; Tursiops truncatus ponticus; Phocoena phocoena relicta; redes de enmalle; capturas accidentales; esfuerzo de pesca; IUU; valores de CPUE.

Citation/Como citar este artículo: Radu G., Anton E. 2014. Impact of turbot fishery on cetaceans in the Romanian Black Sea area. In: Lleonart J., Maynou F. (eds), The Ecosystem Approach to Fisheries in the Mediterranean and Black Seas. Sci. Mar. 78S1: 103-109. doi: http://dx.doi.org/10.3989/scimar.04029.27A

Editors: Jordi Lleonart and Francesc Maynou.

Received: September 25, 2013. Accepted: January 10, 2014. Published: March 29, 2014.

Copyright: () 2014 CSIC. This is an open-access article distributed under the Creative Commons Attribution-Non Commercial Lisence (by-nc) Spain 3.0. 


\section{INTRODUCTION}

The marine mammals living in the Black Sea Romanian littoral waters, represented by the three species Delphinus delphis, Tursiops truncatus and Phocoena phocoena, are particularly vulnerable to a series of threats induced by diverse human activities. These threats are more severe in the Black Sea and the Mediterranean Sea due to their semi-enclosed nature, high human densities, and activities carried out especially in the coastal zones. Aiming to achieve maximum fishing productions, man can cause significant changes in the marine ecosystem with high impact on cetaceans.

The fishery-cetacean interaction is an issue that significantly affects the conservation of cetacean populations:

a) incidental mortality is caused by retention and entanglement in fishing gears;

b) food resources for cetaceans (dolphins are on top of the food chain) are depleted through overfishing, illegal fishing, disturbance of benthic biocoenosis and degradation of specific habitats of marine living resources:

c) cetacean behaviour, normal distribution, migration and reproduction are modified.

Fisheries and marine mammals have an impact on each other because they have similar vital interests, namely fish consumption, most often in the same areas and during the same time intervals.

\section{MATERIALS AND METHODS}

Regular recording of incidental catches started in the entire Black Sea in 1968, but on the Romanian littoral recording began much later and the published data is very scarce after the moratorium for banning the commercial catching of the three cetacean species.

Up to 2001, no projects aimed at the monitoring of incidental catches and stranding of dolphins had been carried out, although research had been carried out on the fish catch, number of fishing gears, number of boats, fishing effort, seasons and fishing locations, fishing yield, and complementary and incidental catch. A research team belonging to the Marine Living Resources Department of the National Institute for Marine Research and Development "Grigore Antipa" (NIMRD), Constanta, who studied the status of fishery resources on the Romanian littoral, also made observations of incidental catches.

In 2001, the NIMRD launched the project "Conservation of the Dolphins from the Black Sea Romanian Waters" and gained financial support for it from the EU Life-Nature programmes. Two of the actions of this project focused on monitoring incidental catch in fishing gears and collecting data on stranding (Moldoveanu et al. 2003, Radu et al. 2002, 2006, Radu and Anton 2004a, Radu 2005).

In order to collect the necessary information, NIMRD had an insufficient network; it was completed with new collaborators through specific partnership agreements with the Border Police, the Constanta Environmental Protection Inspectorate, the Department for
Fishing and Aquaculture of the Ministry of Agriculture, private fishing enterprises and other organizations.

In its Conservation Plan, the Agreement on the Conservation of Cetaceans of the Black Sea, Mediterranean Sea and Contiguous Atlantic Area (ACCOBAMS) stipulated as a conservation measure of cetaceans that all parties shall "collect and analyse data on direct and indirect interactions between humans and cetaceans in relation to inter alia fishing, industrial and touristic activities, and land-based and maritime pollution". Under the conviction that in some countries the basic implementation of the Agreement would be severely constrained by the lack of adequate financial resources, Article IX, paragraph 3 of the Agreement authorizes the Meeting of the Parties "to establish a supplementary conservation grant fund from voluntary contribution $[\ldots]$ in order to increase the funds available for monitoring, research, training and projects relating to the conservation of cetaceans".

Resolution 2.4 of the Second Meeting of the Parties decided the conditions for awarding the grants from the Supplementary Fund. Fulfilling these conditions, the NIMRD prepared the Project and received the financial support for the Project "Assessment of the Extent of Current Cetacean By-catch and Strandings in the Romanian Black Sea Area". The project was carried out from April 2006 to March 2007, in collaboration with the "Mare Nostrum" NGO (Radu et al. 2008).

The Second Project with support from ACCOBAMS was carried out in 2010: "Development of a National Network for Monitoring the Black Sea Cetaceans (Stranded and By-caught) in Romania and Identifying Relevant Measures for the Mitigation of the Adverse Impact of Fisheries" (Radu et al. 2012).

In 2011, the data and information on accidental dolphin catches were provided by both notifications made by IJPF Constanta (Border Police County Inspectorate) and the records made by the NIMRD Constanta during the survey fishing carried-out with the bottom/ mid-water trawl or turbot (Psetta maxima maeotica) gillnets (Table 1).

\section{RESULTS}

\section{Fishing gears used on the Romanian littoral}

A variety of fishing gears are used for active and passive fishing in the Romanian inshore and offshore coastal fishery.

The passive fishing gears generally include the tools for catching the fish migrating for spawning and feeding in shallow waters, namely (Adam et al. 1981):

- longlines and bottom lines;

- gillnets and trammel nets for Danube shad, turbot and sturgeons;

- sea pound nets.

Longlines are the main fishing gears used for spiny dogfish (Squalus acanthias) and goby (Mesogobius batrachocephalus) and auxiliary fishing gears are used for turbot (Psetta maxima maeotica), sturgeon (Acipenser stellatus, Acipenser gueldenstaedti, Huso huso), stringray (Dasyatis pastinaca) and thornback ray (Raja 
Table 1. - Dolphin accidental catches recorded on the Romanian littoral, during the past 10 years

\begin{tabular}{ccccc}
\hline Year & P.phocoena & D. delphis & T. truncatus & Total \\
\hline 2002 & 29 & & & 29 \\
2003 & 9 & & & 9 \\
2004 & & & - \\
2005 & & 2 & - \\
2006 & 20 & & & - \\
2007 & & & - \\
2008 & & & - \\
2009 & 17 & & 54 \\
2010 & 54 & & 54 \\
2011 & & & \\
\hline
\end{tabular}

clavata). Dolphins can become a prey of these fishing gears if they are allured either by the bait in the hooks of the longlines for dogfish or by the small fish such as flounder (Platichthys flesus luscus) and turbot juveniles that are already caught in the longlines.

The bottom lines are traditional fishing gears exclusively used in fishing sturgeons in the Sf. Gheorghe - Ciotic sector. These fishing gears constitute a sort of barrier for sturgeons moving around the sector. Unlike longlines, bottom lines have no bait on the hooks: the fish are caught when trying to cross the hook barrage. Because of the way in which the bottom lines catch big fishes when they try to go beyond the hook curtain, it is very likely that dolphins can also fall prey to these fishing gears when they move around the sectors where they are fixed (Anton 2001).

Danube shad trammel nets are made of three net sheets, a central one having a mesh size of $30 \mathrm{~mm}$ and a thread diameter of $0.3 \mathrm{~mm}$ and two outer ones having a mesh size of $250 \mathrm{~mm}$ and a thread diameter of $0.8 \mathrm{~mm}$. These fishing gears are used to catch the Danube shad shoals off the Romanian coast between late March and mid-May, when this species migrates to the spawning grounds.

Unlike Danube shad trammel nets, turbot gillnets are made of one net sheet having a mesh size of $200 \mathrm{~mm}$ and a thread diameter of $0.5 \mathrm{~mm}$ (Fig. 1). The turbot is caught especially during the spring season (MarchJune), when it migrates to the spawning grounds. Danube shad trammel nets are installed perpendicular to the shore, while turbot gillnets are placed parallel to the shore, at a greater depth at the beginning of the season and gradually at shallower depths.

The gillnets for sturgeons_are made of one sheet, with a thread of 1.4 to $1.5 \mathrm{~mm}$ and a mesh size exceed-

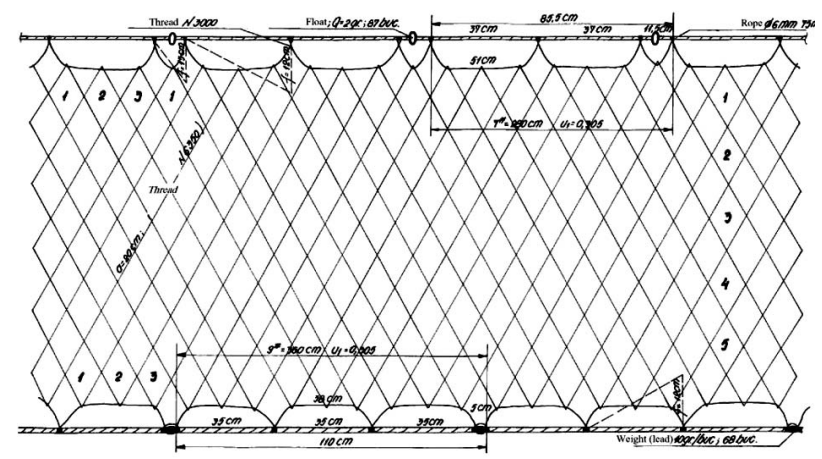

Fig. 1. - Turbot gillnet - hanging details.

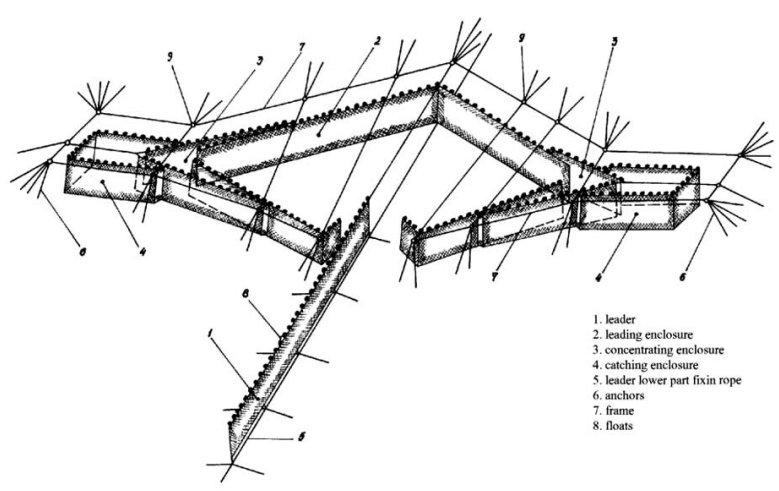

Fig. 2. - Giant pound net to be installed at 9-12 m depth.

ing $100 \mathrm{~mm}$ as per the legislation in force, depending on the target species. Turbot and sturgeon gillnets and Danube shad trammel nets are considered fishing gears that cause victims among the dolphins. These fishing gears are made of thin, less visible and elastic threads that facilitate catching and tangling of the specimens crossing these nets.

Sea pound nets are fishing traps of large dimensions placed at depths of 7 to $12 \mathrm{~m}$ (Fig. 2). The concentration and stopping enclosures are parallel to the shore and reach a length of $70 \mathrm{~m}$. A leader 300-500 long and perpendicular to the shore is used to guide the fish to the trap.

As the marine pound net is made of nets with a small mesh size, it does not facilitate dolphin tangling or catching. This fishing gear is also a large one, so in extreme situations dolphin specimens can enter these installations in search for food. In these cases, the dolphins can become captive, especially in pound nets installed on stakes, in which the aerial wall can be rather high above the water and thus constitute a real barrier for dolphins that enter the catching enclosure.

Another category of fishing gear used in the Romanian coastal zone includes active fishing gear: beach seine and mid-water trawl (Adam et al. 1981). The constructive shape and the retention capacity of the beach seine do not directly endanger dolphin populations. However, there is an indirect disturbing effect of these fishing gears, as they affect some links of the trophic chain that are specific for benthic and pelagic fish, which are in turn food resources for dolphins.

The trawl fishery in the Black Sea is seasonal owing to the limited period when target fish species are present in the area covered by the Romanian coastal trawlers. The trawl influences dolphin populations directly and indirectly. Because these gears have a large filtering surface (ca. $300 \mathrm{~m}^{2}$ ), it is possible for some dolphin specimens to enter the trawl, drown and die in the codend as they cannot get out to breathe (Anton 2001). The trawl can indirectly influence dolphin populations owing to its functioning effects on the biocoenosis components, finally leading to the decrease in food sources as a consequence of intensive and destructive fishing that degrades the environmental conditions.

The number of fishing gears decreased in Romania as follows: number of trawls from 3 to 2; trap 


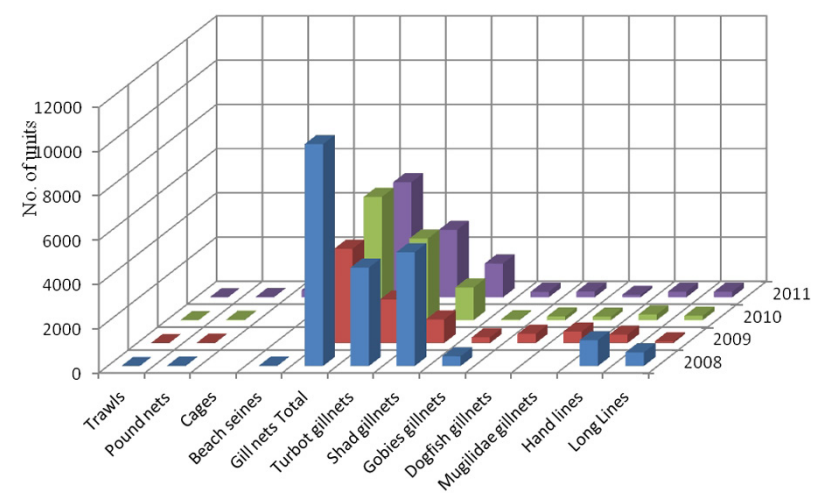

Fig. 3. - Number of units per fishing gear (National Reports 2008-2012/BSC).

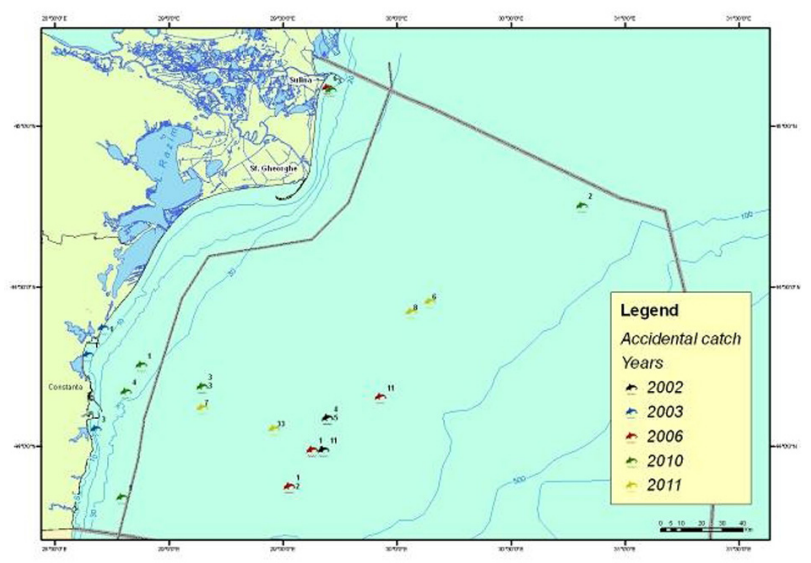

Fig. 4. - Distribution of accidental catches in 2002-2011.

nets from 21 to 15 ; beach seine from 18 to 3 ; gillnets from 10037 to 5202; hand lines from 1172 to 256 and longlines from 620 to 252 (Fig. 3) (National Reports/ BSC. 2002-2011).

\section{Accidental catch (by-catch) in fishing gears}

Each year, tens of dolphins die tragically when they are incidentally caught in the commercial fishing gears. Dolphins are not the target of fishing with these gears but, in search of food, they sometimes find the fishing nets where they get entangled or hooked, so they subsequently drown. The greatest hazard for Black Sea dolphins is turbot gillnets because of their number and area of distribution.

During the study period, incidental catches of dolphins were caused through the fraudulent fishing practiced by the Turkish boats in the Romanian exclusive
Table 2. - Stranded (beached) cetaceans recorded on the Romanian littoral during the past 10 years

\begin{tabular}{cccccc}
\hline Years & P. phocoena & D. delphis & T. truncatus & Unidentified & Total \\
\hline 2002 & 20 & 2 & 13 & 21 & 56 \\
2003 & 78 & 2 & 2 & 37 & 119 \\
2004 & 7 & 2 & 4 & 5 & 18 \\
2005 & 7 & 4 & 4 & 26 & 41 \\
2006 & 33 & 2 & 2 & 67 & 104 \\
2007 & 5 & 3 & 2 & - & 10 \\
2008 & 16 & 1 & 2 & 4 & 23 \\
2009 & 13 & - & 5 & - & 18 \\
2010 & 35 & 1 & 6 & & 42 \\
2011 & 45 & 3 & 4 & & 52 \\
\hline
\end{tabular}

economic zone (EEZ) and through the intensification of the fishing effort carried out with gillnets and trammel nets. In 2002, incidental catches of dolphins were registered during the fraudulent fishing performed by foreign trawlers in the Romanian EEZ in April 2002 (Table 1, Fig. 4) (Anton et al. 2001-2002, 2003, 2004, Radu and Anton 2004b). After the Turkish vessels abandoned the fishing gears at sea, the Romanian authorities had to take the necessary measures to retrieve the gears, to assess the magnitude of the damage, and to diminish the damage to the turbot, dogfish and dolphin populations. The search for gillnets abandoned by the Turkish trawlers resulted in the retrieval of about $40 \mathrm{~km}$ of nets.

We assessed that the total number of dolphins incidentally caught was about 100 , but we could not bring all of them on board because many of the carcasses were in an advanced state of decomposition (the retrieval was carried out over seven days after the arrest of the illegal fishermen) and became detached from the nets during the retrieval.

The number of incidental catches resulting from fraudulent and authorized fishing of turbot using gillnets was 29 specimens belonging to $P h$. phocoena, with lengths between 111.5 and $138 \mathrm{~cm}$; females accounted for $65 \%$.

Following the estimation of the distribution of dolphin strandings on the Romanian littoral, we can summarize that they were recorded between Vama Veche and Portita, especially during the prohibition of turbot fishing (April-June), when this species (preferred food of T. truncatus and Ph. phocoena) makes breeding migrations and the Turkish fishermen tended to practice fraudulent fishing (Tables 2 and 3). Of the dolphins stranded on Romanian beaches, $90 \%$ to $95 \%$ are the result of poaching by Turkish fishermen and, to a smaller extent (given the low fishing effort), by Romanian fishermen's artisanal fisheries using forbidden gears during the prohibition; the remaining 5-10\%

Table 3. - Monthly cetacean strandings recorded on the Romanian littoral during the past 10 years.

\begin{tabular}{|c|c|c|c|c|c|c|c|c|c|}
\hline Year & February & March & April & May & June & July & August & September & Total \\
\hline 2002 & - & 1 & 7 & 39 & 4 & 1 & 2 & 2 & 56 \\
\hline 2003 & - & - & 5 & 18 & 3 & 83 & 10 & - & 119 \\
\hline 2004 & - & & 5 & 4 & 7 & - & 1 & 1 & 18 \\
\hline 2005 & - & - & 3 & 13 & 2 & 18 & 3 & 2 & 41 \\
\hline 2006 & - & 6 & 9 & 30 & 20 & 35 & 1 & 3 & 104 \\
\hline 2007 & 1 & - & 1 & 1 & 2 & 2 & 3 & - & 10 \\
\hline 2008 & 1 & - & 4 & 5 & 9 & 2 & 2 & - & 23 \\
\hline 2009 & - & - & 7 & 3 & 5 & 1 & 2 & - & 18 \\
\hline 2010 & & & 6 & 4 & 7 & 20 & 2 & 3 & 42 \\
\hline 2011 & & & 3 & 34 & 5 & 7 & 3 & & 52 \\
\hline
\end{tabular}


Table 4. - Abandoned gears in 2011.

\begin{tabular}{ll}
\hline Period & Number of fishing gears \\
\hline January & 14 monofilament gears abandoned at sea \\
February & 25 monofilament gears abandoned at sea \\
March & 5 monofilament gears abandoned at sea \\
April & 106 monofilament gears abandoned at sea \\
May & 39 monofilament gears and gillnets abandoned at sea \\
June & 129 monofilament gears and gillnets abandoned at sea \\
July & 24 monofilament gears abandoned at sea \\
August & 10 monofilament gears abandoned at sea \\
September & 6 monofilament gears abandoned at sea \\
October & 8 monofilament gears abandoned at sea \\
\hline
\end{tabular}

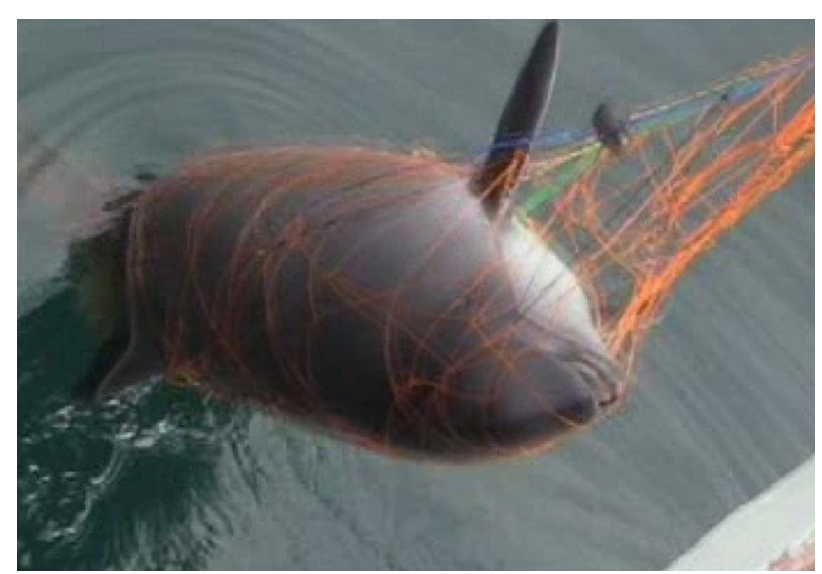

Fig. 5. - Cetaceans incidentally caught in gillnets.

are caused by disease and natural mortality. Usually, the carcasses showed marks produced by the mesh nets and scars on the flippers, dorsal fins and flukes caused by the gillnet filaments (Figs 5, 6 and 7) (Anton et al. 2001/2002, 2003, 2004; Radu and Anton 2004b).

In 2003, 9 cetaceans pertaining to $P h$. phocoena were accidentally caught in the fishing gears (gillnets, pound nets, pelagic trawl) used in the Romanian industrial fishery (Table 1, Fig. 4). The number of incidental catches was 2.2 times lower than in 2002 (Radu and Anton 2004b; Anton et al. 2008).

In 2004 and 2005, no incidental catches were formally registered and the strandings were fewer than in previous years (Tables 2 and 3 ).

In 2006, cetacean incidental catches were identified in the industrial fishing with gillnets in four situations involving 22 specimens of the species Phocoena and

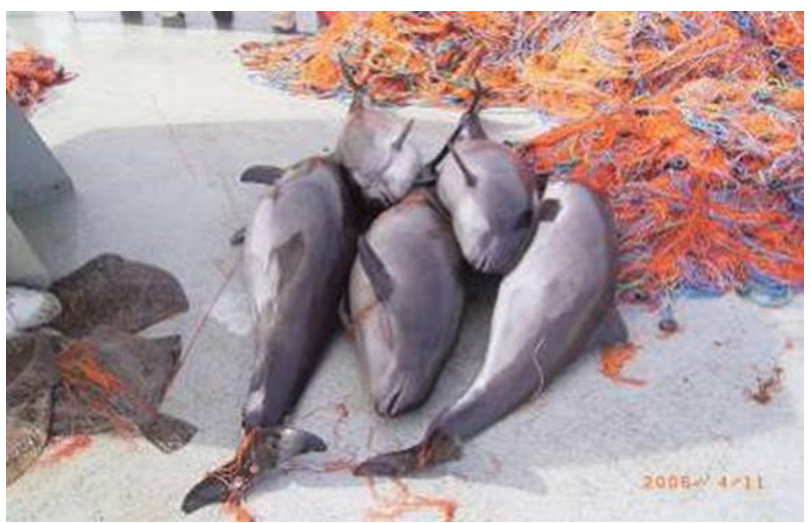

Fig. 6. - Cetaceans incidentally caught in Turkish gillnets, recovered by the patrolling boats of the Constanța Border Police.

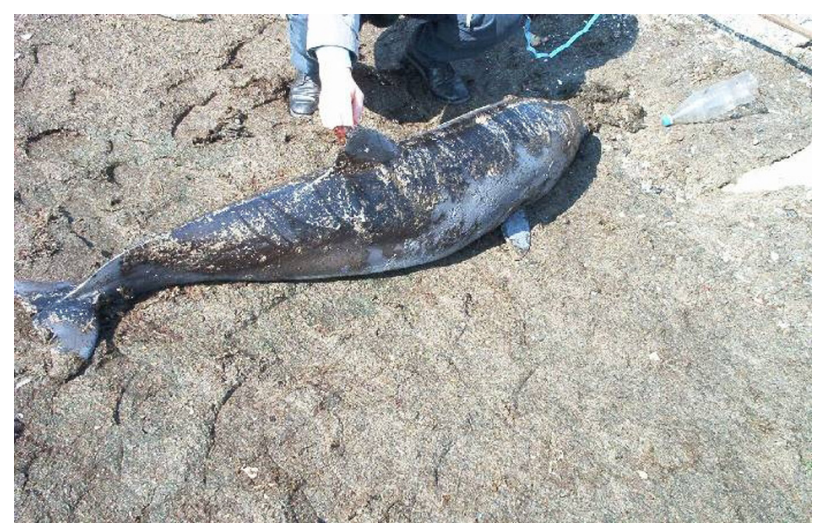

Fig. 7. - Stranded Phocoena - marks produced by the mesh nets.

Tursiops (Table 1, Fig. 4). The frequency of occurrence for Tursiops in turbot/sturgeon gillnets was $9 \%$, and for Phocoena $91 \%$. This high frequency of Phocoena can be explained by the smaller dimensions of its body in relation to the mesh size and thread thickness, and its lesser ability to free itself from the nets in comparison with large species (Anton et al. 2008, Radu et al. 2008).

In 2007, 2008 and 2009, no incidental catch was officially recorded and strandings were fewer than in previous years (Tables 1, 2 and 3).

In 2010, 17 specimens of Phocoena caught accidentally were recorded and, in 2011, 54 specimens of Phocoena were recorded (Table 1, Fig. 4).

In the period analysed, the majority of accidental cetacean catches in gillnet gears involved the species Phocoena phocoena, which proved to be the most vulnerable to this type of fishing.

\section{Ghost fishing (abandoned nets)}

When abandoned gillnets lifted on board control vessels, by-caught dolphins are often found, usually decayed. These "ghost" tools are built in series with no markings, mechanically armed and especially designed for bottom stationary fishing. According to existing data (Report of the National Agency for Fisheries and Aquaculture), the total length of the "ghost" nets found since 2006 to date is about $90 \mathrm{~km}$.

The situation of abandoned gears in 2011 is presented in Table 4.

\section{Estimated CPUE values of cetacean by-catches}

According to the information from economic agents practising specialized turbot fishing, on the Romanian coast the average number of dolphins accidentally caught by turbot gillnets with mesh size of $200 \mathrm{~mm}$ in regular checks (4-5 days, but conditional upon the weather) is 1-2 dolphins in 30-40 gillnets (Radu 2011, Radu et al. 2012).

From an interview with a vessel skipper it was ascertained that in 150 gillnets with an average length of $60 \mathrm{~m}$, the cetacean by-catch, especially of Phocoena, is about seven specimens. When turbot gillnets show a higher number of by-caught dolphins, the main cause is that they are not checked in due time (4-5 days). Field in- 
vestigations revealed that more than $95 \%$ of the dolphins stranded on the Romanian Black Sea coast had been accidentally caught in gillnets (for turbot, dogfish etc.).

\section{Impact of fisheries on cetaceans}

Fisheries can have a series of effects on cetaceans:

- modification (depletion or increase) of feeding possibilities;

- behavioural modification;

- alteration of the distribution, migration and breeding capacity.

Pelagic and coastal fishery can affect the cetacean populations through the overexploitation of the species that are feeding resources for them. Fishing activity can change the dolphins' feeding behaviour and strategy. They are sometimes seen near trawlers and hauling trawls, and near or even in passive fishing gears (pound nets, gillnets and longlines).

Dolphin habitats are degrade by fishing gears in several ways:

- great numbers of fixed gears, pound nets, gillnets etc. can considerably reduce the vital space for dolphins and increase the possibility of being entangled;

- bottom trawling, in addition to its direct danger to dolphins, can destroy the benthic fauna, thus eliminating important links of the food chain;

- mid-water trawl hauling is also a direct threat, as there is the possibility of entanglement, but it also acts on the food resources; as it is very unselective, it can affect both adults and juveniles.

However, taking into account the number and area of coverage, turbot gillnets are the most dangerous fishing gears for Black Sea cetaceans.

\section{CONCLUSIONS AND RECOMMENDATIONS}

The marine mammals living in the Romanian Black Sea littoral waters, represented by the three species Delphinus delphis, Tursiops truncatus and Phocoena phocoena, are particularly vulnerable to a series of threats induced by human activities.

The fishery-cetacean interaction is an issue that significantly affects the conservation of cetacean populations, through incidental mortality produced by retention and entanglement in fishing gears; depletion of food resources for cetaceans through overfishing (dolphins are a the top of the food chain), illegal fishing, benthic biocoenosis disturbance and degradation of specific habitats of marine living resources; deterioration of cetacean habitats; and modification of cetacean behaviour, distribution, migration and reproduction. Each year, tens of dolphins die tragically, being incidentally caught in the commercial fishing gears.

In the coastal fishing performed on the Romanian littoral, both in shallow and offshore waters, many types of gears designed for passive and active fishing are used. They act in both coastal and offshore waters, using stationary and filtrating hauled gears. In the offshore fishery, the most widely used gears are midwater trawl, turbot and spiny dogfish gillnets and spiny dogfish longlines. In the coastal fishery, the gears most used by the fishing enterprises are marine pound nets and gillnets.

The incidental catches of dolphins were caused by the fraudulent fishing practiced by Turkish vessels in the Romanian EEZ and through the intensification of the fishing effort carried out with gillnets and trammel nets by local fishermen. Most, if not all, recorded accidental catches of dolphins in gillnet gears involved the species Phocoena phocoena, which proved to be the most vulnerable to this type of fishing.

The most hazardous areas in relation to increased cetacean mortality are connected to the distribution of the turbot agglomerations and, implicitly, the distribution and size of the fishing effort (number of gillnets). An imminent threat to cetacean populations are abandoned or lost gillnets (as a result of observations, they remain functional and continue to retain individuals that they intersect).

According to information from economic agents practising specialized turbot fishing, on the Romanian coast the average number of dolphins accidentally caught by turbot gillnets with a mesh size of $200 \mathrm{~mm}$, for a regular check (4-5 days, but conditional upon the weather), is 1-2 dolphins in 30-40 gillnets. When turbot gillnets show a higher number of by-caught dolphins, the main cause is that they are not checked in due time. More than $95 \%$ of entangled cetaceans, mainly of the species Phocoena phocoena, will die.

\section{How can this problem be solved?}

- Increasing the awareness of sustainable exploitation by issuing legislation that is applicable immediately.

- Drawing up protection programmes on areas and periods, based on the behaviour of certain economically valuable species, mainly strongly correlated with stock evolution, and increasing the selectivity of fishing gear.

- Enhancing control in areas prone to poaching and discouraging access to these areas, as well as extending operations by creating joint inspection teams from the riparian countries.

- Improving communication in cases of spotting of IUU activities, followed-up by immediate penalties.

- Registering vessels/boats on IUU "black lists" and forbidding the right to operate for 3-5 years and, in case of relapse, permanently.

\section{REFERENCES}

Adam A., Bogatu D., Rauta M., Jelescu N., Nicolau C., Firulescu C. 1981. Pescuitul industrial. Editura tehnică, Bucureşti.

Anton E. 2001. Analiza sistemelor actuale de captură utilizate în pescuitul comercial şi evaluarea riscului de capturare accidentală a delfinilor. Raport tehnic. INCDM, Constanţa.

Anton E., Nicolaev S., Radu G., Radu E., Adam A., Adam A. 2001/ 2002. Researches on the incidental dolphin catches during the illegal commercial fishing. The annales of "Lower Danube" University of Galaţi, Fascicle VII - Fishing and aquaculture 7: 25-32.

Anton E., Nicolaev S., Radu G., Radu E., Adam A., Adam A. 2003. Research on the incidental dolphin catches during the illegal commercial fishing. Simpozion internaţional "Euro-Aliment 2003”, Galaţi, 23-25 Oct. 2003. 
Anton E., Nicolaev S., Radu G., Radu E., Adam A., Adam A. 2004. Researches on the incidental dolphin catches during the illegal commercial fishing. The annales of "Lower Danube" University of Galaţi, Fascicle VII - Fishing and aquaculture, ISSN 1453-0821.

Anton E., Nicolaev S., Radu G., Radu E., Maximov V., Staicu I., Papadopol N.C., 2008. Observations sur la distribution et la fréquence d'apparition des captures accidentelles de dauphins sur le littoral roumain au cours de l'année 2006. Cercetări marine. Recherches marines. INCDM 38: 251-268.

BSC. 2002-2011. National Reports of the Black Sea Commission.

Moldoveanu M., Radu G., Ionescu L. 2003. Obiectivele, actiunile si realizarile obţinute în primul an de desfăţurare (2002) a Proiectului LIFE-Natura "Conservarea Delfinilor din Apele Româneşti ale Mării Negre". A 55-a Reuniune Anuală a Comitetului stiințific al Comisiei Internaționale pentru Balene (IWC). Berlin, Germania, 26 mai- 2 iunie 2003.

Radu G., Anton E., Moldoveanu M., Radu E., Ionescu L. 2002. Conservarea delfinilor din apele românești ale Mării Negre. Marea Noastră, issue 3 (44): 26-27.

Radu G., Anton E. 2004a. Date privind proiectul "Conservarea delfinilor din apele românesti ale Mării Negre". Workshop on the use of acoustic devices in the ACCOBAMS area: preparation of guidelines. Organizat de Secretariatul ACCOBAMS, Rome - 28 June 2004.

Radu G., Anton E. 2004b. Situația capturilor accidentale si a eşuărilor de delfini la litoralul românesc. Workshop on the use of acoustic devices in the ACCOBAMS area: preparation of guidelines. Organizat de Secretariatul ACCOBAMS, Rome - 28 June 2004.
Radu G. 2005. Realizările obținute de către INCDM în cadrul Proiectului Life Conservarea delfinilor din apele românesti ale Mării Negre. A treia întâlnire a Comitetului ştiințific ACCOBAMS (Acordul privind conservarea cetaceelor din Marea Neagră, Marea Mediterană și zona contiguă Oceanului Atlantic), 12-18 mai 2005, Cairo, Egipt.

Radu G., Radu E., Anton E., Staicu I., Moldoveanu M. 2006. Main results obtained through the realization of the Life-Natura project "Conservation of dolphins from the Romanian Black Sea waters". Cercetări marine. Recherches marines. INCDM, 36: 447-458.

Radu G., Anton E., Radu E., Florea A. 2008. Results obtained in the frame of the ACCOBAMS project "Assessment of the extent of present cetacean by-catch and strandings in the Romanian Black Sea area". Cercetări marine. Recherches marines. INCDM, 38: 233-250.

Radu G. 2011. Summary of the Project "Development of a National Network for Monitoring the Black Sea Cetaceans (Stranded and By-Caught) in Romania and Identifying Relevant Measures for the Mitigation the Adverse Impact of Fisheries. 14th regular FOMLR AG meeting of the BSC, Black Sea Commission Permanent Secretariat Premises, Istanbul, Turkey, 19-20 September, 2011.

Radu G., Nicolaev S., Anton E., Maximov V., Dumitrache C., Cândea M., Fabian R. 2012. Summary of the Project "Development of a National Network for Monitoring the Black Sea Cetaceans (Stranded and By-caught) in Romania and Identifying Relevant Measures for the Mitigation of the Adverse Impact of Fisheries". Cercetări marine. Recherches marines. INCDM. 42: 121-138. 